\title{
Relationship between Fibre Characteristics and Physico-Mechanical Properties of Aningeria robusta (A.CHEV) Wood
}

\author{
Olaoye K.O. ${ }^{1}$, Oluwadare A.O. ${ }^{2}$, and Ariwoola O.S. ${ }^{3}$ \\ ${ }^{1,3}$ Federal College of Forestry, Forestry Research Institute of Nigeria, Jericho, Ibadan, Nigeria \\ Corresponding email: snipeskay@gmail.com \\ ${ }^{2}$ Department of forest products and production, University of Ibadan, Ibadan, Nigeria \\ aoluwada@gmail.com
}

\begin{abstract}
Aningeria robusta wood is fast becoming popular in Nigeria, due to its excellent performance in structural applications especially in roofing, and in recent times, door frames and furniture. Thus, consideration must be given to its mechanical properties, and fibres in wood is known for providing mechanical support for the wood. Notwithstanding, mechanical failure of wood in service still occurs. To limit such failures assessment is needed to be done on some parameters associated to quality of wood. This study thus assess the relationship between fibre characteristics and physico-mechanical properties of Aningeria robusta wood. Three trees of Aningeria robusta were obtained wood samples of $20 \times 20 \times 300 \mathrm{~mm}$ were collected to determine modulus of elasticity and modulus of rupture (mechanical property), 20X20X20mm for fibre characteristics, and 20x20x60mm for wood density and moisture content. The mean fibre length, fibre diameter, lumen, cell wall thickness (CWT), $1.55 \mathrm{~mm}, 11.71 \mu \mathrm{m}$, $8.78 \mu \mathrm{m}, 1.46 \mu \mathrm{m}$, while the mean moisture content, density, modulus of rupture (MOR) and modulus of elasticity (MOE) were $55.54 \%, 429.34 \mathrm{~kg} / \mathrm{m}^{3}, 123.91 \mathrm{~N} / \mathrm{mm}^{2}, 5876.89 \mathrm{~N} / \mathrm{mm}^{2}$ respectively. There existed a negatively significant correlation between fibre length and MOR, and well as CWT and moisture content. This existing relationship implies that the shorter the fibre length, the more the MOR. It can therefore be concluded that existing relationship between fibre characteristics and physico-mechanical properties taken cognisance of where mechanical failure of wood is to be limited.
\end{abstract}

Keywords-A.robusta wood, fibre, mechanical, physical, relationship.

\section{INTRODUCTION}

The wood of Aningeria robusta is fast becoming popular due to its excellent performance in structural applications especially in roofing, and in recent times, door frames and furniture. Aningeria robusta belongs to the family Sapotaceae, a hardwood. It is referred to as 'agengre' in Cote d'Ivoire, 'landosan' in Nigeria and 'osan' in Uganda (TRADA 1979 cited in Ajala and Ogunsanwo, 2011), 'mukali' in Angola, 'mukangu' in Kenya (Chudnoff 1980 cited in Ajala and Ogunsanwo, 2011) and 'asafonia' in Ghana (Okai 2003).

Wood fibre are usually a thread like cellulosic elements that are extracted from trees and used to make materials including paper, paperboard, tissue, cardboard etc. However, its main function in a tree is to provide mechanical support. Sizes of fibre cell wall range from thinwalled to thick-walled fibre depending on the wood species. Physical properties are the quantitative characteristics of wood and its behavior to external influences other than applied forces. Density and moisture content are some of the relevant physical properties of wood that are relevant to wood structural performance. Familiarity with physical properties is important because they can significantly influence the performance and strength of wood used in structural applications (Winandy, 1994). Mechanical properties are the characteristics of a material in response to externally applied forces. They include elastic properties such as modulus of elasticity, which relate the resistance of a material to deformation under an applied stress to the ability of the material to regain its original dimensions when the stress is removed, and modulus of rupture, which measures wood strength before rupture when load is applied. Mechanical property values are given in terms of stress (force per unit area) and strain (deformation resulting from the applied stress.

Also, Samuel 2004 stated that mechanical properties of wood are its fitness and ability to resist applied or external forces. This means that mechanical properties 
determines to a large extent the use of wood for structural and building purposes.

There has been records of wood failure when in use, and these failures may be attributed to poor mechanical factors. Samuel 2004 reported that a buckling and bending failure will occur where the fibre walls of a wood show gradations of thickness i.e. transition from the thin-walled cells of the early wood to the thick-walled cells of the late wood is gradual. Also that moisture in wood decreases the stiffness of the fibre walls and enlarges the region of failure. It can therefore be stated that the manner of failure depends partly upon the anatomical structure and partly upon the degree of humidity of the wood, such that the fibres (tracheids in conifers) act as hollow tubes bound closely together, and can buckle or bend when force is applied.

Therefore, to limit the failure of wood in service, it is imperative to assess the wood quality parameters. This involves the consideration of anatomical such as fibre characteristics, physical and mechanical properties of wood. Thus, the objective of this study is to investigate the relationship between fibre characteristics and physicomechanical properties of Aningeria robusta (A.chev) wood.

\section{MATERIALS AND METHOD}

Three trees of Aningeria robusta with at least $25 \mathrm{~cm}$ DBH were obtained from Onigambari Forest Reserve. From each tree, bolts were collected at the base, middle and top portion, and the wood samples was processed using circular machine and planning machine to a dimension of 20x20x300mm for modulus of elasticity and modulus of rupture (mechanical property), 20X20X20mm for fibre characteristics, $20 \times 20 \times 60 \mathrm{~mm}$ for wood density and moisture content according to ASTM, 1991.

\subsection{Determination of Fibre Characteristics}

For the fibre dimensions determination, small slivers were obtained each at the different sampling height. The slivers were placed in an equal volume (1:1) of $30 \%$ hydrogen peroxide and $10 \%$ glacial acetic acid, boiled until soft and bleached white (ASTM D 1413-61 2007). The slivers were then washed, placed in $30 \mathrm{~mL}$-test tubes with $20 \mathrm{~mL}$-distilled water and shaken vigorously to separate the fibre bundles into individual fibre. The macerated fibre suspension was carefully aligned on a slide using a rubber teat. The resulting image on Rheichert visopan microscope screen was measured for fibre length, diameter, lumen width and cell wall thickness was calculated with relevant formular.
The 20x20x60mm wood samples collected were oven dried to a constant weight at $103^{\circ} \mathrm{C} \pm 2$ for 24 hours and the weight afterward was recorded. The volume of samples at green weight was recorded and the following formula was adopted for the calculation of wood density.

$$
\begin{aligned}
& \qquad D=\frac{m}{v}\left(\mathrm{~kg} / \mathrm{m}^{3}\right) \\
& D=\text { Density } \\
& m=\text { oven-dried mass } \\
& v=\text { green volume }
\end{aligned}
$$

\subsection{Determination of Moisture Content}

The samples were weighed when wet (original weight), it was then dried to a constant weight at $103^{\circ} \mathrm{c} \pm 2$ in an oven for 24 hours, after which it was re-weighed. The loss of weight of the wood samples on drying to a constant weight was noted. Calculation of the loss in weight as a percentage of the samples weight after drying was done by using the formula below

$$
\begin{aligned}
& M C=\frac{w w-o w}{o w} \times 100 \\
& M C=\text { Moisture Content } \\
& w w=\text { wet weight } \\
& o w=\text { oven dry weight }
\end{aligned}
$$

2.4 Determination of Modulus of Rupture (MOR) and Modulus of Elasticity (MOE)

This involved the use of standard test specimen (20 x 20 x 300mm), in a universal testing machine. The test sample was prepared in such a way that growth rings will be made parallel to one edge. Load was applied at the rate of $0.2 \mathrm{~mm} / \mathrm{sec}$, with the growth rings parallel to the direction of loading, that is, specimen was loaded on the radial face. From the graph generated by the universal testing machine, the peak and breaking force were recorded; hence MOR and MOE was calculated as thus;

$$
M O R=\frac{3 P L}{2 b d^{2}}\left(N / \mathrm{mm}^{2}\right)
$$

(3)

$$
M O E=\frac{P L^{3}}{4 \Delta b d^{3}}\left(N / \mathrm{mm}^{2}\right)
$$

Where: 
$P=$ load in Newton $(\mathrm{N})$

$L=$ span $/$ length (mm)

$B=$ width (mm)

$D=\operatorname{depth}(\mathrm{mm})$

$\Delta=$ the displacement at beam centre at proportional load

\section{RESULTS AND DISCUSSION}

Table 1 shows the axial variation in fibre characteristics of A.robusta wood. Mean for Fibre length, fibre diameter, lumen diameter and cell wall thickness were $1.55 \mathrm{~mm}, \quad 11.71 \mu \mathrm{m}, \quad 8.78 \mu \mathrm{m}, \quad 1.46 \mu \mathrm{m}$ respectively. Meanwhile, Table 2 shows the selected physical and mechanical properties tested for the wood sample, while Table 3 shows the correlation analysis between these properties.

Anon, (1984) stated that a mean fibre length of $1.6 \mathrm{~mm}$ and above are classified as long fibre. Therefore, fibre length of A.robusta was considered short. As reported by Kpikpi (1992), some Nigerian hardwood species also had value within this value. Although the fibre length of A.robusta was short, yet it compared favourably with some Nigerian wood species. Meanwhile, the observed fibre diameter for A.robusta was lower to other selected wood species considered with it for comparism. Ogunleye et al., (2017) recorded $41.5 \mu \mathrm{m}$ for Ricinodendron heudelotii wood, $30.67 \mu \mathrm{m}$ was recorded for G. arborea (Roger et al., 2007) while 36.09 and $34.25 \mu \mathrm{m}$ for $R$. racemosa and $R$. harrisonii, respectively (Emerhi 2012), and $20.3 \mu \mathrm{m}$ for $T$. scleroxylon (Ogunsanwo 2000). Similarly, lumen diameter and cell wall thickness of A.robusta wood had values which compared lower to the selected wood species aforementioned.

Wood density obtained in this study was similar to Chudnoff (1980) $\left(400-480 \mathrm{~kg} / \mathrm{m}^{3}\right)$, Ajala and Ogunsanwo (2011) (430 kg/m3) for $A$. robusta but slightly lower to
Arowosoge et al., (2008) $\left(510 \mathrm{~kg} / \mathrm{m}^{3}\right)$, and Okai (2003) $(500$

$\mathrm{kg} / \mathrm{m}^{3}$ ) for the same species. Age and location could have contributed to these differences (Arowosoge et al., 2008). Furthermore, the mean MOE value obtained in the course of this study is slightly lower $(5876.89 \mathrm{~N} / \mathrm{mm} 2)$ to what was obtained by Ajala and Ogunsanwo (2011); a reason for this may be an effect of wood maturity, and/or inconsideration of radial pattern.

Existing relationship between fibre characteristics and selected physico-mechanical properties revealed that fibre length had a negatively significant correlation with wood density and MOR alone. Similarly, cell wall thickness had a negatively significant correlation with moisture contents only. This implies that the shorter the fibre length of A.robusta wood, the more its wood density and MOR. Also that, a thinner cell wall will means more moisture content.

This relationship is tenable because shorter fibres could mean larger percentage of fibre, which in turn equate to higher MOR. Uetimane and Ali (2011) supports this tendency in their work which showed a significant positive relationship in fibre length and MOR for sapwood. One of the parameters that determines high density is the amount of mass of a substance. Then, higher fibre percentage may also be responsible for higher density. Thus, supporting the relationship observed in this study. However, Emmanuel (2014) recorded no significant correlation between any of the fibre characteristics and physico-mechanical properties of selected wood species but recorded a significant difference among wood species sample. The resulting no significant correlation could have been caused by a significant difference in wood species samples tested. Thus, this study suggests that determining correlation of wood properties of more than one species should be done independently, as a significant difference among species may alter correlation analysis.

Table.1: Axial variation in fibre characteristics of Aningeria robusta wood

\begin{tabular}{ccccccc}
\hline Sampling Height & TREE & FL(mm) & FD( $\boldsymbol{\mu m})$ & LD $(\boldsymbol{\mu m})$ & $\mathbf{C W T}(\boldsymbol{\mu m})$ \\
\hline TOP & 1 & $1.73 \pm 0.06$ & $11.83 \pm 0.22$ & $10.13 \pm 0.29$ & $0.85 \pm 0.07$ \\
& 2 & $1.37 \pm 0.03$ & $10.67 \pm 0.37$ & $8.16 \pm 0.49$ & $1.26 \pm 0.08$ \\
MIDDLE & 3 & $1.51 \pm 0.03$ & $11.48 \pm 0.24$ & $10.45 \pm 0.25$ & $0.52 \pm 0.05$ \\
& MEAN & & $\mathbf{1 . 5 4} \pm \mathbf{0 . 1 0}$ & $\mathbf{1 1 . 3 3} \pm \mathbf{0 . 3 4}$ & $\mathbf{9 . 5 8} \pm \mathbf{0 . 7 1}$ & $\mathbf{0 . 8 8} \pm \mathbf{0 . 2 1}$ \\
& 1 & $2.04 \pm 0.49$ & $12.21 \pm 0.41$ & $8.43 \pm 0.52$ & $1.89 \pm 0.12$ \\
& 2 & $1.34 \pm 0.03$ & $10.99 \pm 0.33$ & $6.67 \pm 0.40$ & $2.16 \pm 0.26$ \\
& 3 & $1.52 \pm 0.05$ & $12.43 \pm 0.58$ & $9.60 \pm 0.61$ & $1.42 \pm 0.28$ \\
& MEAN & & $\mathbf{1 . 6 3} \pm \mathbf{0 . 2 1}$ & $\mathbf{1 1 . 8 8} \pm \mathbf{0 . 4 5}$ & $\mathbf{8 . 2 3} \pm \mathbf{0 . 8 5}$ & $\mathbf{1 . 8 2} \pm \mathbf{0 . 2 2}$
\end{tabular}




\begin{tabular}{cccccc}
\hline BASE & 1 & $1.44 \pm 0.16$ & $12.64 \pm 0.63$ & $9.12 \pm 0.62$ & $1.76 \pm 0.02$ \\
& 2 & $1.44 \pm 0.09$ & $11.41 \pm 0.46$ & $8.00 \pm 0.31$ & $1.71 \pm 0.17$ \\
MEAN & 3 & $1.54 \pm 0.06$ & $11.73 \pm 0.31$ & $8.59 \pm 0.30$ & $1.57 \pm 0.13$ \\
P. MEAN & & $\mathbf{1 . 4 7} \pm \mathbf{0 . 0 3}$ & $\mathbf{1 1 . 9 3} \pm \mathbf{0 . 3 7}$ & $\mathbf{8 . 5 7} \pm \mathbf{0 . 3 2}$ & $\mathbf{1 . 6 8} \pm \mathbf{0 . 0 6}$ \\
& & $\mathbf{1 . 5 5} \pm \mathbf{0 . 0 7}$ & $\mathbf{1 1 . 7 1} \pm \mathbf{0 . 2 1}$ & $\mathbf{8 . 7 8} \pm \mathbf{0 . 3 8}$ & $\mathbf{1 . 4 6} \pm \mathbf{0 . 1 7}$
\end{tabular}

FL - Fibre Length

CWT - Cell Wall Thickness
FD - Fibre Diameter

P. mean - Pooled mean
LD - Lumen Diameter

$46 \pm 0.17$

Table.2: Mean values of physico-mechanical properties determined for A. robusta

\begin{tabular}{|c|c|c|c|c|}
\hline & TREE 1 & TREE 2 & TREE 3 & MEAN \\
\hline \multicolumn{5}{|l|}{$\mathrm{MC} \mathrm{( \% )}$} \\
\hline TOP & 58.02 & 62.65 & 65.12 & $61.93 \pm 2.08$ \\
\hline MIDDLE & 38.79 & 48.44 & 57.65 & $48.29 \pm 5.44$ \\
\hline BASE & 65.88 & 48.49 & 54.77 & $56.38 \pm 5.08$ \\
\hline MEAN & $54.23 \pm 8.04$ & $53.19 \pm 4.72$ & $59.18 \pm 3.08$ & $55.54 \pm 2.98$ \\
\hline \multicolumn{5}{|l|}{ WOOD } \\
\hline \multicolumn{5}{|c|}{ DENSITY $\left(\mathrm{kg} / \mathrm{m}^{3}\right)$} \\
\hline TOP & 380.42 & 407.5 & 434.50 & $407.47 \pm 15.61$ \\
\hline MIDDLE & 361.67 & 517.67 & 452.92 & $444.08 \pm 45.24$ \\
\hline BASE & 412.25 & 515.25 & 381.92 & $436.472 \pm 40.35$ \\
\hline MEAN & $384.77 \pm 14.76$ & $480.14 \pm 36.32$ & $423.11 \pm 21.2$ & $429.34 \pm 18.91$ \\
\hline \multicolumn{5}{|l|}{$\operatorname{MOR}\left(\mathbf{N} / \mathbf{m m}^{2}\right)$} \\
\hline TOP & 122.1 & 129.51 & 129.56 & $127.06 \pm 2.47$ \\
\hline MIDDLE & 95.04 & 116.33 & 145 & $118.79 \pm 14.47$ \\
\hline BASE & 116.73 & 136.87 & 124.08 & $125.893 \pm 5.88$ \\
\hline MEAN & $111.29 \pm 8.27$ & $127.57 \pm 6.0$ & $132.88 \pm 6.26$ & $123.91 \pm 4.74$ \\
\hline \multicolumn{5}{|l|}{ MOE (N/mm²) } \\
\hline TOP & 5807.8 & 6435.92 & 6609.44 & $6284.39 \pm 243.50$ \\
\hline MIDDLE & 5754.87 & 5576.14 & 5660.49 & $5663.83 \pm 51.62$ \\
\hline BASE & 6862.52 & 3176.22 & 7008.62 & $5682.45 \pm 1253.82$ \\
\hline MEAN & $6141.73 \pm 360.71$ & $5062.76 \pm 975.37$ & $6426.18 \pm 399.81$ & $5876.89 \pm 382.82$ \\
\hline \multicolumn{4}{|c|}{ IOR $=$ Modulus of rupture,$* * \mathrm{MOE}=$ modulus of elasticity } & Table.3: Pearson correlation analysis between fibre characteristics and physico-mechanical properties \\
\hline & Wood density & Moisture content & MOR & MOE \\
\hline Fibre length & $-0.66^{*}$ & -0.54 & $-0.63^{*}$ & 0.03 \\
\hline Fibre diameter & -0.36 & 0.01 & -0.16 & 0.17 \\
\hline Lumen width & -0.50 & 0.55 & 0.29 & 0.36 \\
\hline $\mathrm{CWT}^{* * *} *$ & 0.30 & $-0.62 *$ & -0.48 & -0.29 \\
\hline
\end{tabular}

\section{CONCLUSION AND RECOMMENDATION}

This study was successful in establishing the relationship that existed between fibre characteristics and physico- mechanical properties of A.robusta wood, and as such this existing relationship should be taken into consideration where mechanical failure of wood is intended to be limited. 
Thus, recommending more studies into the relationship of other anatomical and physico-mechanical properties that wasn't considered in the scope of this study.

\section{REFERENCES}

[1] Ajala, O.O and Ogunsanwo, O.Y. (2011): Specific gravity and mechanical properties of Aningeria robusta wood from Nigeria; Journal of tropical forest science 23(4): 389-395

[2] American Society for Testing and Materials (ASTM). ASTM D 1030-95 - Standard test method for fibre analysis of paper and paperboard. West Conshohocken, PA. 2007.

[3] American Society for Testing and Materials (ASTM, 1991): Standard test methods for specific gravity of wood and wood-based materials D2395-02. Annual Book of ASTM Standards. Section 4. Volume 04.10. West Conshohocken, PA. USA: 844 p.

[4] Anon, (1984). Chemical Analysis of Nigerian Grown timbers. Annual Report of the Forestry Research Institute of Nigeria (FRIN). Jan- Dec pp 108-109.

[5] Arowosoge, O.G.E. Ogunsanwo O.Y. and Labode, P. (2008): Techno-economic analyses of wood species utilized in furniture industry in selected cities of Nigeria. Journal of Food, Agriculture \& Environment, Vol.6 (3\&4) 486

[6] Chudnoff, M. (1980): Tropical Timbers of the World. Agricultural Handbook No. 607. USDA Forest Service, Forest Products Laboratory, Madison.

[7] Emerhi E. A. (2012): Variations in anatomical properties of Rhizophora racemosa (Leechm) and Rhizophora harrisonii (G. Mey) in a Nigerian mangrove forest ecosystem. International Journal of Forest, Soil and Erosion, 2(2): 89-96

[8] Emmanuel Tete Okoh (2014): Fibre, Physical and Mechanical Properties of Ghanaian Hardwoods. Journal of Energy and Natural Resources. Vol. 3, No. 3, 2014, pp. 25-30. doi: 10.11648/j.jenr.20140303.11

[9] Kpiki W.M. (1992): Wood structure and paper making potentials of Ricinodendron heudelotii and Albizia zygia in relation to Gmelina arborea. Nigerian Journal of Botany, 5:41-50

[10] Okai, R. (2003): Characterization of moisture content and specific gravity of branch wood and stem wood of Aningeria robusta and Terminalia ivorensis. Holz als Roh-und Werkstoff 61: 155-158.

[11] Ogunleye Bolade Mercy, Fuwape Joseph Adeola, Oluyege Amos Olajide, Ajayi Babatunde and Fabiyi James Sunday (2017): Evaluation Of Fiber Characteristics Of Ricinodedron Heudelotii (Baill,
Pierre Ex Pax) For Pulp And Paper Making. International Journal of Science and Technology Volume 6 No. 1, January, 2017. Pg. 634-641

[12] Ogunsanwo O.Y. (2000). Characterisation of wood properties of plantation grown Obeche (Triplochiton scleroxylon) in Omo Forest Reserve, Ogun State. Ph.D. thesis. Dept of Forest Resources Management, University of Ibadan. 253P.

[13] Roger M. R., Mario T. F. and Edwin C. A (2007). Fibre morphology in fast growth Gmelina arborea plantations. Madera Bosques 13(2):3-13.

[14] Samuel (2004): Project Gutenberg's. The Mechanical Properties of Wood, by Samuel J. Record. May 8, 2004 [EBook \#12299)

[15] Uetimane E. Jr and AC Ali (2011): Relationship between mechanical properties and selected anatomical features of ntholo ("pseudolachnostylis maprounaefolia") Journal of Tropical Forest Science Vol. 23, No. 2 (April 2011), pp. 166-176 (11 pages)

[16] Winandy, J.E. 1994. Effects of long-term elevated temperature on CCA-treated Southern Pine lumber. Forest Products Journal. 44(6): 49-55. 